\title{
Efficacy of D5F3 IHC for detecting ALK gene rearrangement in NSCLC patients: a systematic review and meta-analysis
}

\author{
Hu Ma ${ }^{1, *}$, Wen-Xiu Yao ${ }^{2, *}$, Lang Huang ${ }^{1, *}$, Su-Han Jin ${ }^{3}$, Da-Hai Liu ${ }^{1}$, Yuan Liu ${ }^{4}$, Xu \\ Tian $^{5}$, Jin-Hui Tian ${ }^{6}$, Jian-Guo Zhou ${ }^{1}$ \\ ${ }^{1}$ Department of Oncology, Affiliated Hospital of Zunyi Medical University, Zunyi 563000, China \\ ${ }^{2}$ Department of Oncology, Affiliated Cancer Hospital of Medical School, University of Electronic Science and Technology \\ of China, Sichuan Cancer Hospital and Institute \& Cancer, The Second People's Hospital of Sichuan Province, Chengdu, \\ 610000, China \\ ${ }^{3}$ Affiliated Stemmatological Hospital of Zunyi Medical University, Zunyi 563000, China \\ ${ }^{4}$ Department of Pharmacology and Key Laboratory of Basic Pharmacology of Ministry of Education, Zunyi Medical University, \\ Zunyi 563000, China \\ ${ }^{5}$ Chongqing Cancer Hospital and Institute, Chongqing, 40030, China \\ ${ }^{6}$ Evidence-Based Medicine Center of Lanzhou University, Lanzhou, 730000, China \\ "These authors have contributed equally to this work
}

Correspondence to: Jian-Guo Zhou, email: jianguo.zhov@yahoo.com

Keywords: NSCLC, D5F3, ALK, diagnostic accuracy, meta-analysis

Received: June 06, $2016 \quad$ Accepted: August 13,2016 Published: September 01, 2016

\section{ABSTRACT}

We conducted a pooled analysis comparing the efficacy of an immunohistochemistry (IHC) assay using the D5F3 antibody with that of fluorescence in situ hybridization (FISH) for detecting ALK gene rearrangement in NSCLC patients. A total of 32 studies involving 5805 samples were included in this review. Pooled sensitivity for D5F3 IHC was 0.97 (95\%CI: 0.93-0.98), specificity was 0.99 (95\%CI: 0.98-1.00), PLR was 119.20 (95\%CI: 57.79-245.89), NLR was 0.03 (95\%CI: $0.02-0.07$ ), DOR was 3526.66 (95\%CI: 1344.71-9249.03), and AUROC was 1.00 (95\%CI: 0.99-1.00). Metaregression revealed that specimen type was a source of heterogeneity for specificity, and specimen type and FISH signal distance were sources of heterogeneity in the joint model. Subgroup analysis revealed that sensitivity and specificity were higher when the FISH signal distance standard was $\geq 2$ than when it was $\geq 1$. Sensitivity was higher for tumor specimens than for cell specimens; specificity was higher for cell specimens than for tumor specimens. In conclusion, the D5F3 IHC assay was nearly as effective as FISH for detection of ALK gene rearrangement in NSCLC patients.

\section{INTRODUCTION}

Lung cancer is one of the most frequency diagnosed and deadly cancers worldwide, and non-small cell lung cancer (NSCLC) accounts for more than $85 \%$ of lung cancer cases $[1,2]$. Anaplastic lymphoma kinase (ALK) gene rearrangement is responsible for approximately $3 \%$ $5 \%$ of NSCLC cases $[3,4]$. Studies have reported that ALKtyrosine kinase inhibitors (ALK-TKIs) increase response rate [5-7] and progression-free survival times [8] in ALK fusion-positive NSCLC patients. NCCN guidelines thus recommend detection of ALK gene fusion in metastatic NSCLC, and the use of the ALK-TKI crizotinib as a firstline treatment in ALK-positive patients [9].
It is therefore crucial to assess the efficacy of different methods for detecting ALK rearrangement. At present, fluorescence in situ hybridization (FISH), polymerase chain reaction (PCR), and immunohistochemistry (IHC) are commonly used to detect ALK fusion. NCCN guidelines recommend FISH as the gold standard for detecting ALK fusion [10], but FISH is expensive and labor-intensive. Studies examining polymerase chain reaction (PCR) for detection of ALK rearrangement found that PCR had high diagnostic performance compared to FISH [11, 12]. However, PCR also resulted in a high false positive rate, suggesting that high-quality RNA is needed for this method [13]. Recently studies [14-16] have also examined the clinical use of IHC with D5F3, 5A4, 
and ALK1 antibodies, the most cost-effective method, for detecting ALK rearrangement. Jiang et al. [17] conducted a meta-analysis of the diagnostic operating characteristics of IHC and concluded that IHC assays using D5F3 and 5A4 antibodies reliably detected ALK rearrangement in NSCLC. However, this study did not examine the diagnostic value of IHC screening methods using the D5F3 antibody. Although the D5F3 antibody is commonly used in the clinical setting, its efficacy remains largely unknown; we therefore conducted a systematic review and meta-analysis to assess the diagnostic accuracy of the D5F3 antibody in detecting ALK rearrangement.

\section{RESULTS}

\section{Selection of studies}

A total of 352 literature citations were identified in database searches and 1 citation was identified from reference lists. Ultimately, 32 studies [12, 14, 15, 22-50] containing 37 trials and 5905 samples that met the inclusion criteria were included in this metaanalysis. 833 of these samples were positive and 4845 were negative for ALK gene rearrangement. Shen et al. [24] examined automated or manual detection of a D5F3 clone (Ventana) to detect ALK rearrangement; the rest of the studies used a different D5F3 clone (CST). Zhou et al. [12] used two difference samples, while Fu et al. [28] used EML4-ALK and ALK probes, to detect ALK rearrangement by FISH. Ying et al. [41] used two IHC positive standards. Figure 1 shows a flow diagram of the literature research process.

\section{Characteristics of included studies}

All eligible studies were published between 2012 and 2015, and 19 of the studies were from China. Each study included one trial, with the following exceptions: Shen et al. [24] included 3 trials, Zhou et al. [12] involved 2 trails, Fu et al. [28] involved 2 parallel trials, and Ying et al. [41] included 2 trials. Of the 32 studies, 23 studies examined NSCLC specifically and 9 studies examined lung adenocarcinoma. Tumor tissues or cell blocks were used as FISH specimens, and details of the FISH and IHC procedures differed among the studies. The main characteristics of the included studies are shown in Supplementary Data 1.

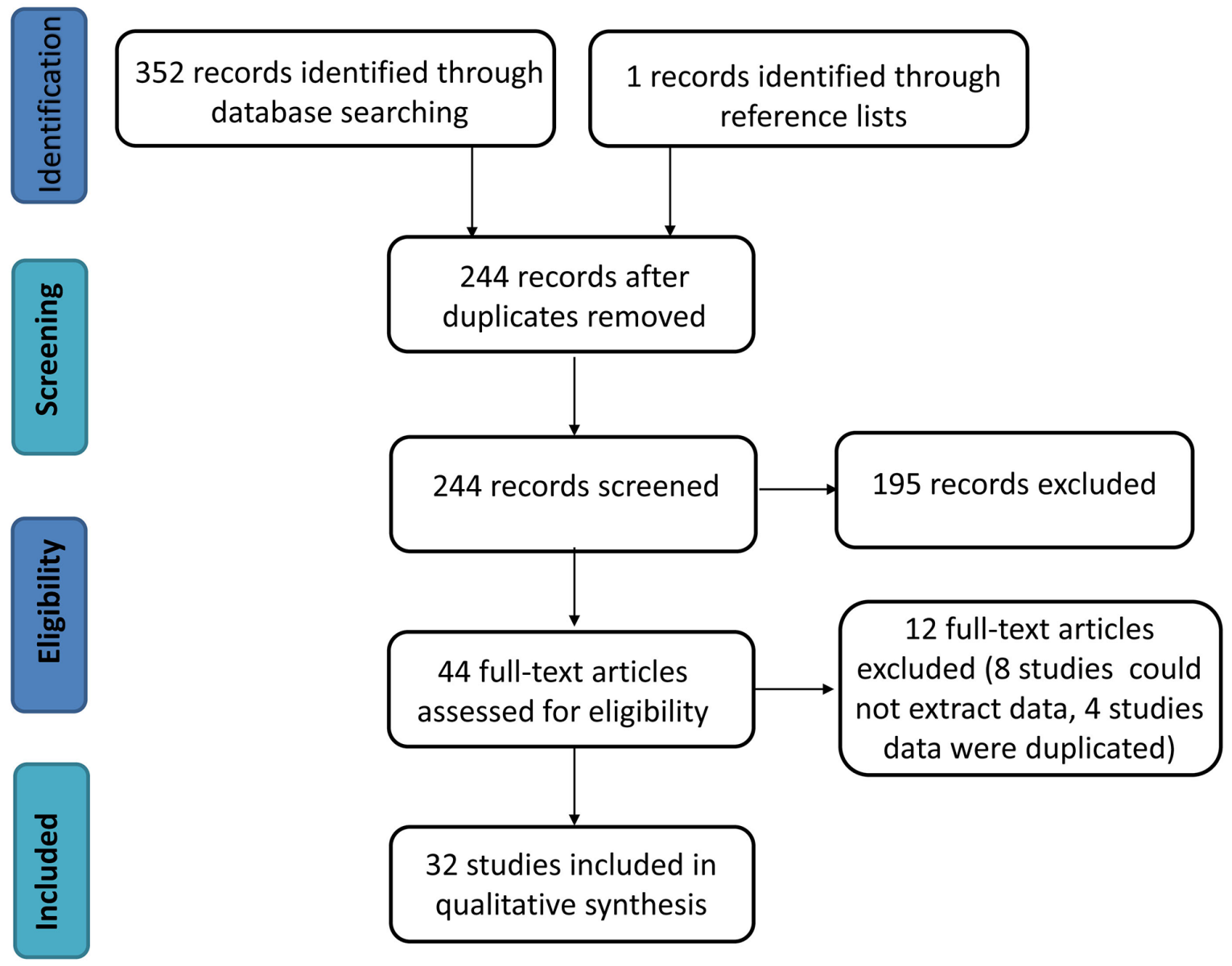

Figure 1: Flow chart of the systematic review process. 


\section{Quality assessment}

The methodological quality of the 32 studies was assessed using the QUADAS-2 tool. Risk of bias analysis revealed that 21 studies had high bias in flow and timing, 8 studies had high bias in patient selection, 5 studies had high bias in index tests, and 1 study had high bias in reference standard. Regarding applicability concerns, 31 studies had low bias in reference standard, 7 studies had low bias in index tests, and 30 studies had low bias in patient selection. Finally, the overall quality was acceptable. The details of methodological quality analysis of the included studies are summarized in Figures 2 and 3.

\section{Diagnostic performance}

5905 samples were involved in this meta-analysis, and the overall pooled sensitivity of IHC for detection ALK fusion was 0.97 (95\% CI: 0.93-0.98) (Figure 4), the specificity was 0.99 (95\%CI: 0.98-1.00) (Figure 5), the PLR was 119.20 (95\%CI: 57.79-245.89), the NLR was 0.03 (95\%CI: 0.020.07 ), the DOR was 3526.66 (95\%CI: 1344.71-9249.03), and the AUROC was 1.00 (95\%CI: 0.99-1.00). Significant heterogeneity existed in this meta-analysis (Figure 6). As shown in Figure 7, the summary LRP and LRN for PCR was in the left upper quadrant (LUQ), indicating that the D5F3 IHC assay was a critical exclusion and confirmation method for detecting ALK fusion. The summary receiver operator characteristic (SROC) curve (Figure 8) indicated that the D5F3 IHC assay had high diagnostic performance in detecting ALK gene rearrangement; the corresponding area under the SROC curve (AUC) was 1.00 (95\%CI:0.99-1.00). As shown in Figure 9, the clinical utility of D5F3 IHC for detecting ALK rearrangement was good, and the post-test probability (PLR: 97\%, NLR: 1\%) was greater than the pretest probability $(20 \%)$.

\section{Meta-regression analysis}

The overall $I^{2}$ was 96.50 , and the boxplot (Figure 6) showed that heterogeneity existed in the studies. Therefore, meta-regression was used to investigate potential sources of heterogeneity. Sample size, country, histological type, cells counted using FISH, FISH signal distance, supplier, manual or automated counting, specimen type, and IHC positive standard were included in the meta-regression analysis of sensitivity, specificity, and the joint model. Metaregression results are shown in Table 1 and indicated that specimen type was a likely source of heterogeneity for specificity; specimen type and FISH signal distance were likely sources of heterogeneity for the joint model.

\section{Subgroup analysis}

The results of subgroup analysis are shown in Table 2. Different FISH standards influenced the sensitivity and specificity of IHC. When FISH signal distance standard was $\geq 2$, the sensitivity was 0.987 (95\%CI: 0.983-0.991) and specificity was 0.983 (0.9780.987 ); when the standard was $\geq 1$, the sensitivity was $0.952(0.881-0.987)$ and the specificity was 0.963 (95\%CI: 0.933-0.982). Regarding sample type, the sensitivity and specificity were 0.984 (95\%CI: 0.960 $0.996)$ and $0.965(95 \% \mathrm{CI}: 0.951-0.976)$ for tumor samples and 0.936 (95\%CI: $0.914-0.954)$ and 0.987 (95\%CI: 0.983-0.991) for cell samples, respectively. Finally, sensitivity and specificity were higher when the FISH standard was at least 2 than when it was at least 1 . Additionally, sensitivity was higher for tumor specimens than for cell specimens, while specificity was higher for cells than for tumors.

\section{Publication bias}

We used Deek's funnel plots of $1 \mathrm{nDOR}$ against $1 /$ $\mathrm{ESS}^{1 / 2}$, or, equivalently, against $(1 / n 1+1 / n 2)^{1 / 2}$, which is proportional to $1 / \mathrm{ESS}^{1 / 2}$, to assess the accuracy of diagnostic tests [40]. The $p$ value obtained from the funnel plot was 0.001 , indicating the presence of publication bias in this meta-analysis (Figure 10).

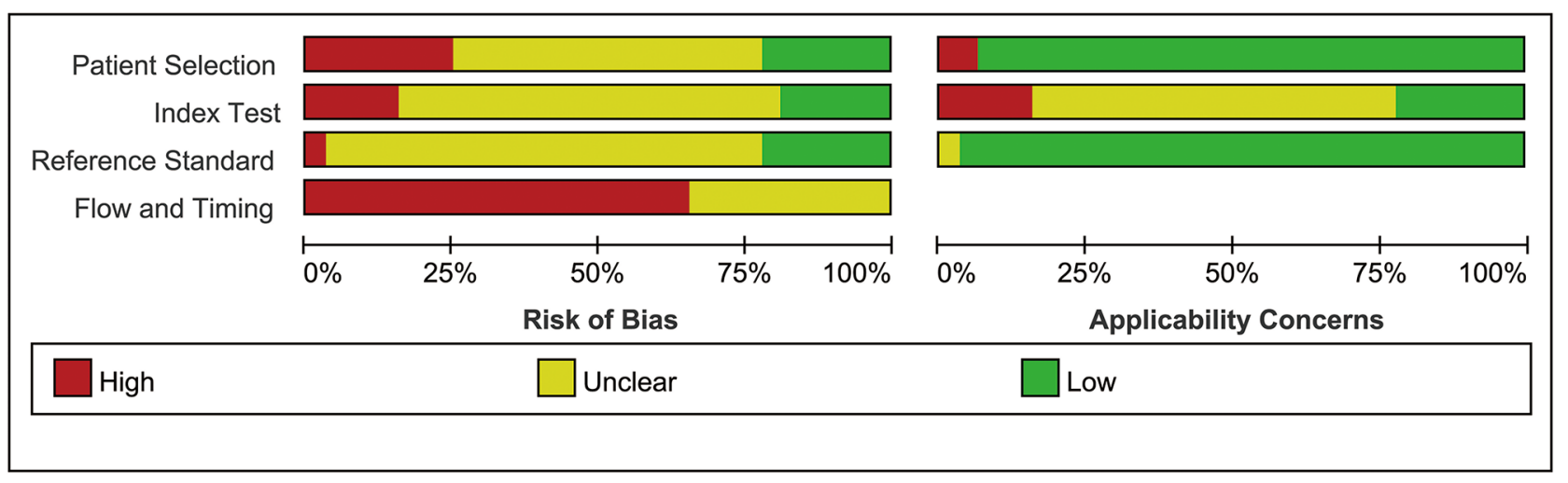

Figure 2: Risk of bias and applicability concerns summary. 


\section{Level of evidence}

TP, FP, TN, and FN were included in the Grade profile. The evidence qualities of TP and FN were moderate, and TN and FP were low. The evidence quality results are shown in Table 3.

\section{DISCUSSION}

Siegel et al. first reported the presence of ALK rearrangement in NSCLC in 2007 [51]. While ALK fusion was previously found to occur in approximately 3\%-5\% of NSCLC patients [3,4], we found ALK rearrangement

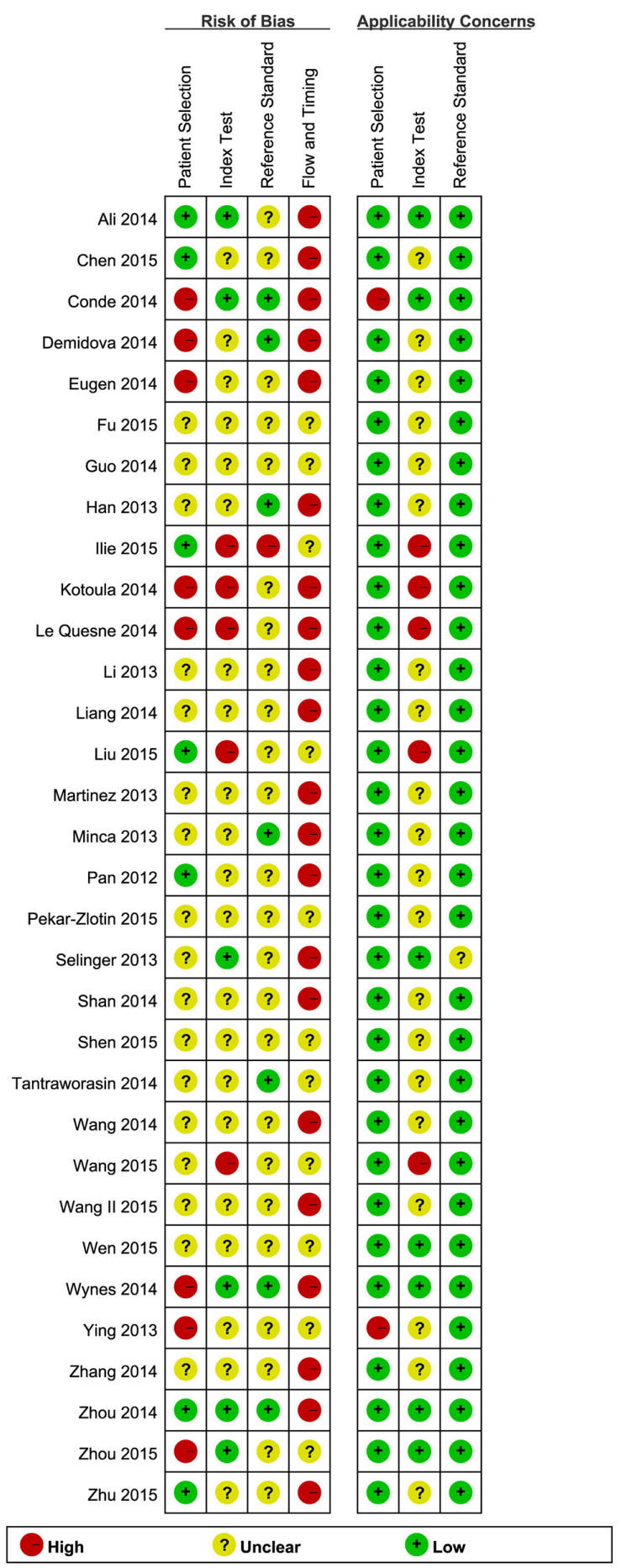

Figure 3: Risk of bias and applicability concerns graph. 


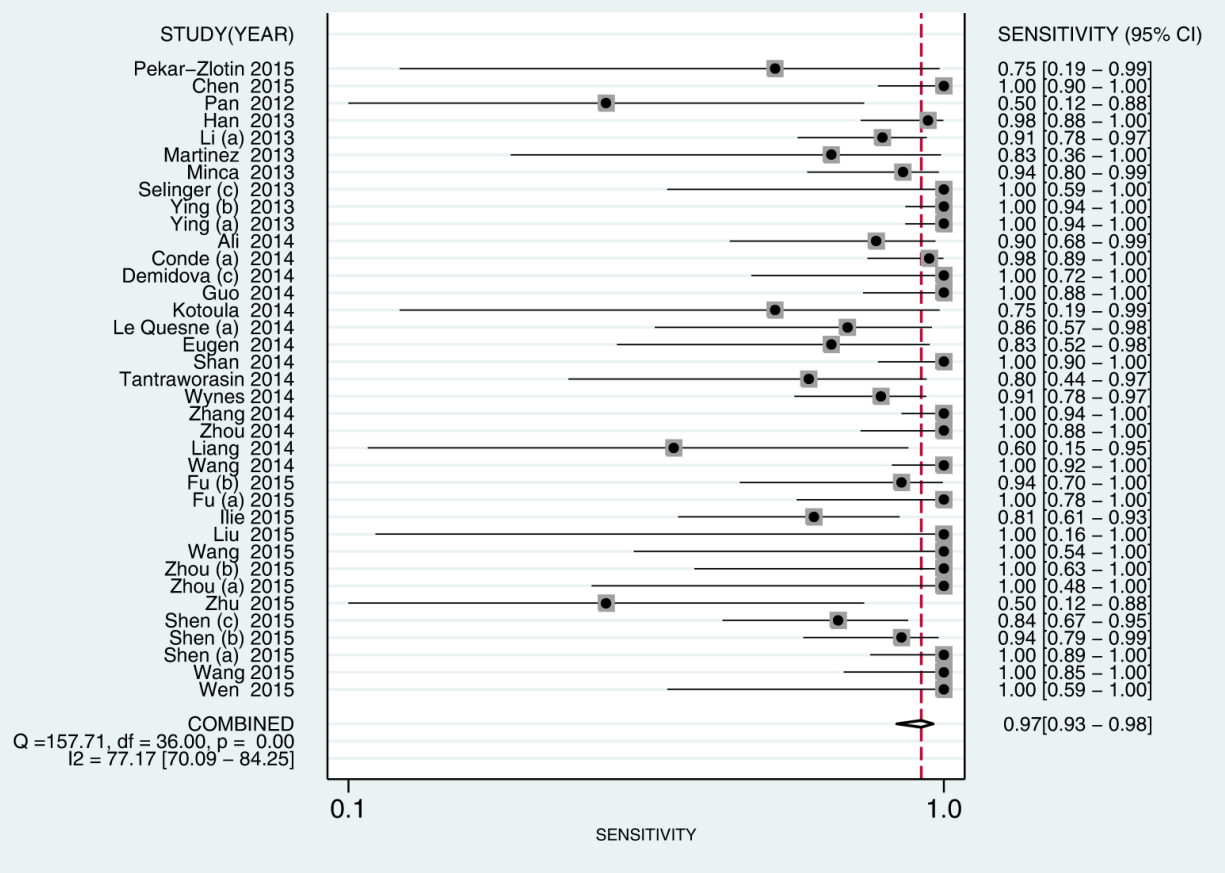

Figure 4: Forest plot estimating sensitivity of ALK rearrangement detection by D5F3 IHC in NSCLC patients in the selected studies. Point estimates for sensitivity and $95 \%$ CIs are shown with pooled estimates; IHC = Immunohistochemistry; NSCLC = non-small cell lung cancer; ALK = anaplastic lymphoma kinase; $\mathrm{CI}=$ confidence interval; $\mathrm{Q}=$ Cochran $\mathrm{Q}$ statistic.

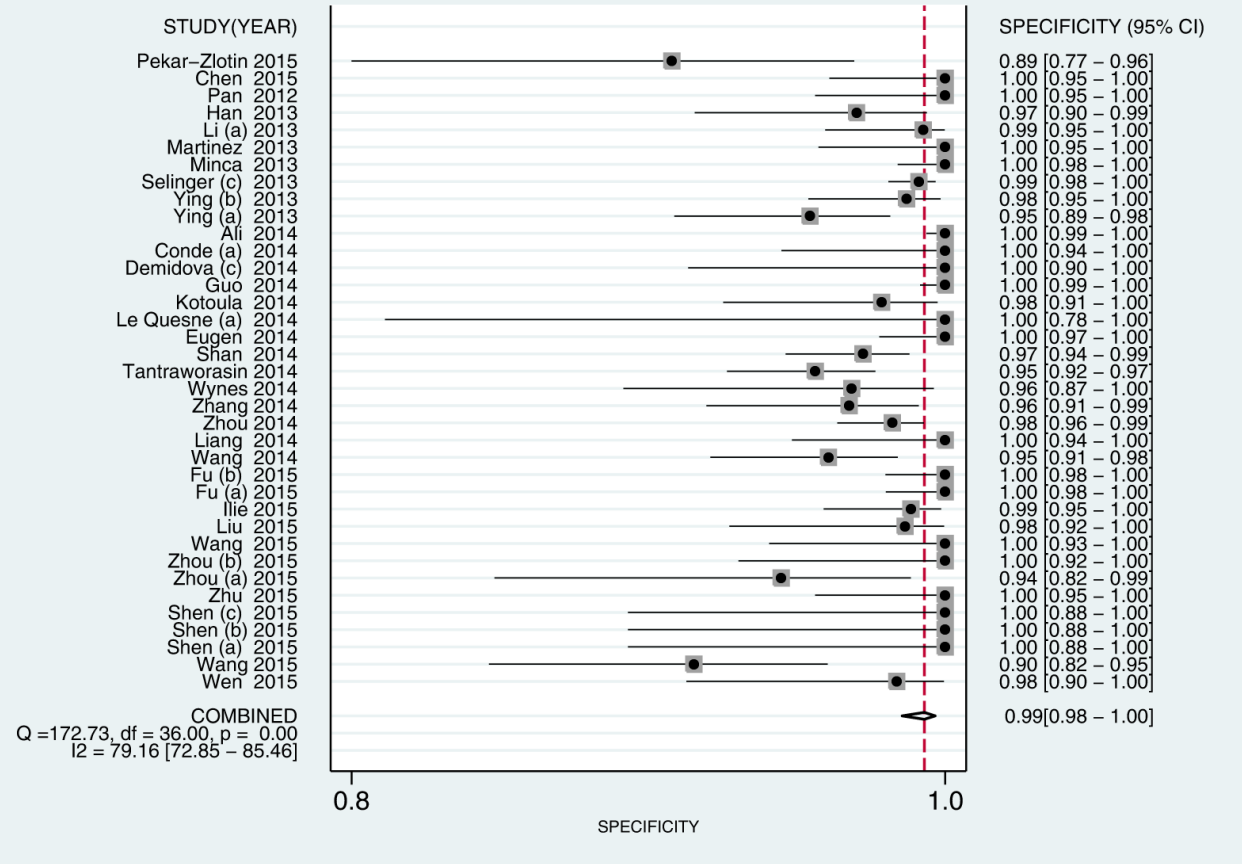

Figure 5: Forest plot estimating specificity of ALK rearrangement detection by D5F3 IHC in NSCLC patients in the selected studies. Point estimates for specificity and $95 \%$ CIs are shown along with pooled estimates; IHC = Immunohistochemistry; $\mathrm{NSCLC}=$ non-small cell lung cancer; $\mathrm{ALK}=$ anaplastic lymphoma kinase; $\mathrm{CI}=$ confidence interval; $\mathrm{Q}=$ Cochran $\mathrm{Q}$ statistic. 


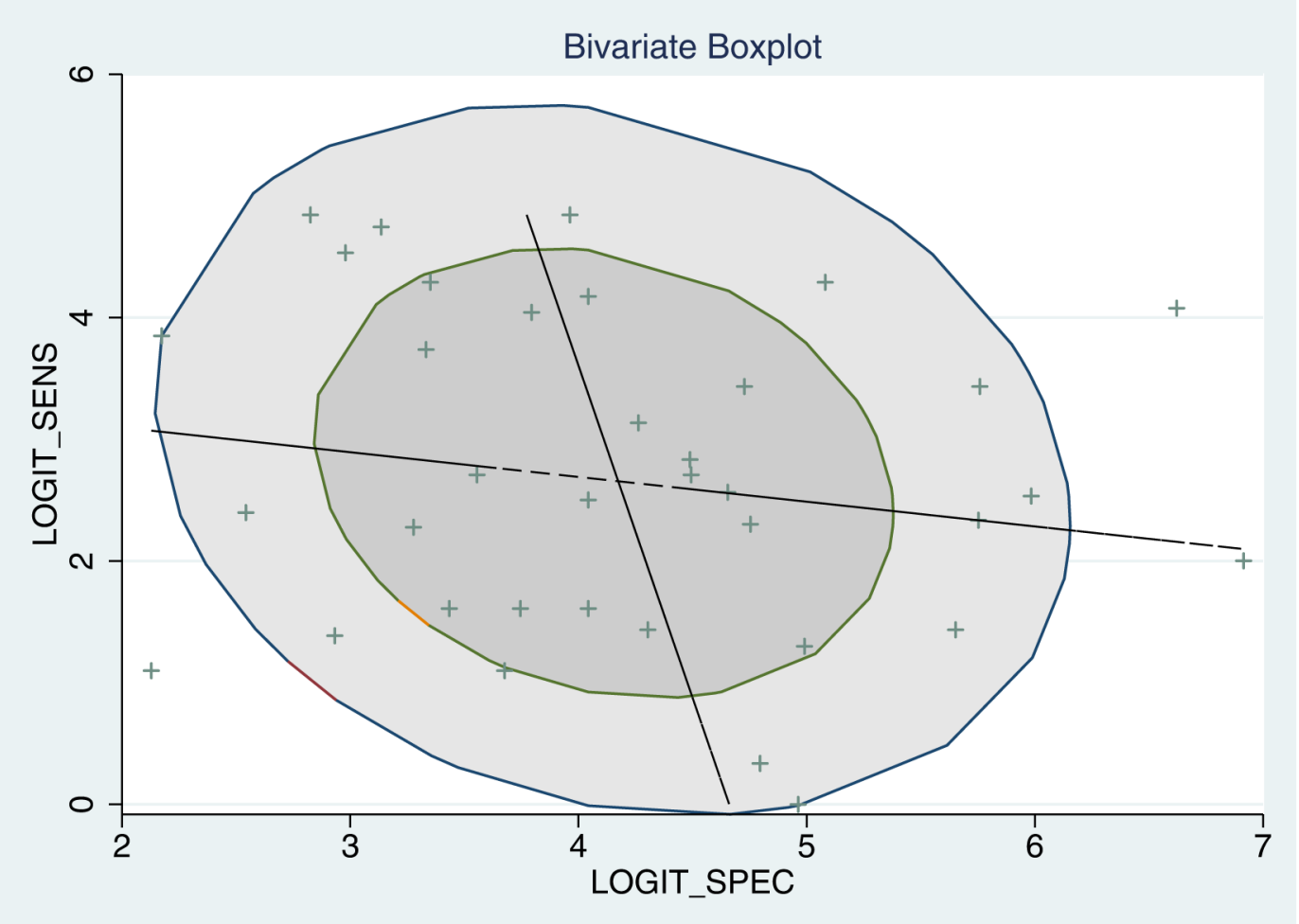

Figure 6: Bivariate boxplot of sensitivity and specificity in the 37 included trials.

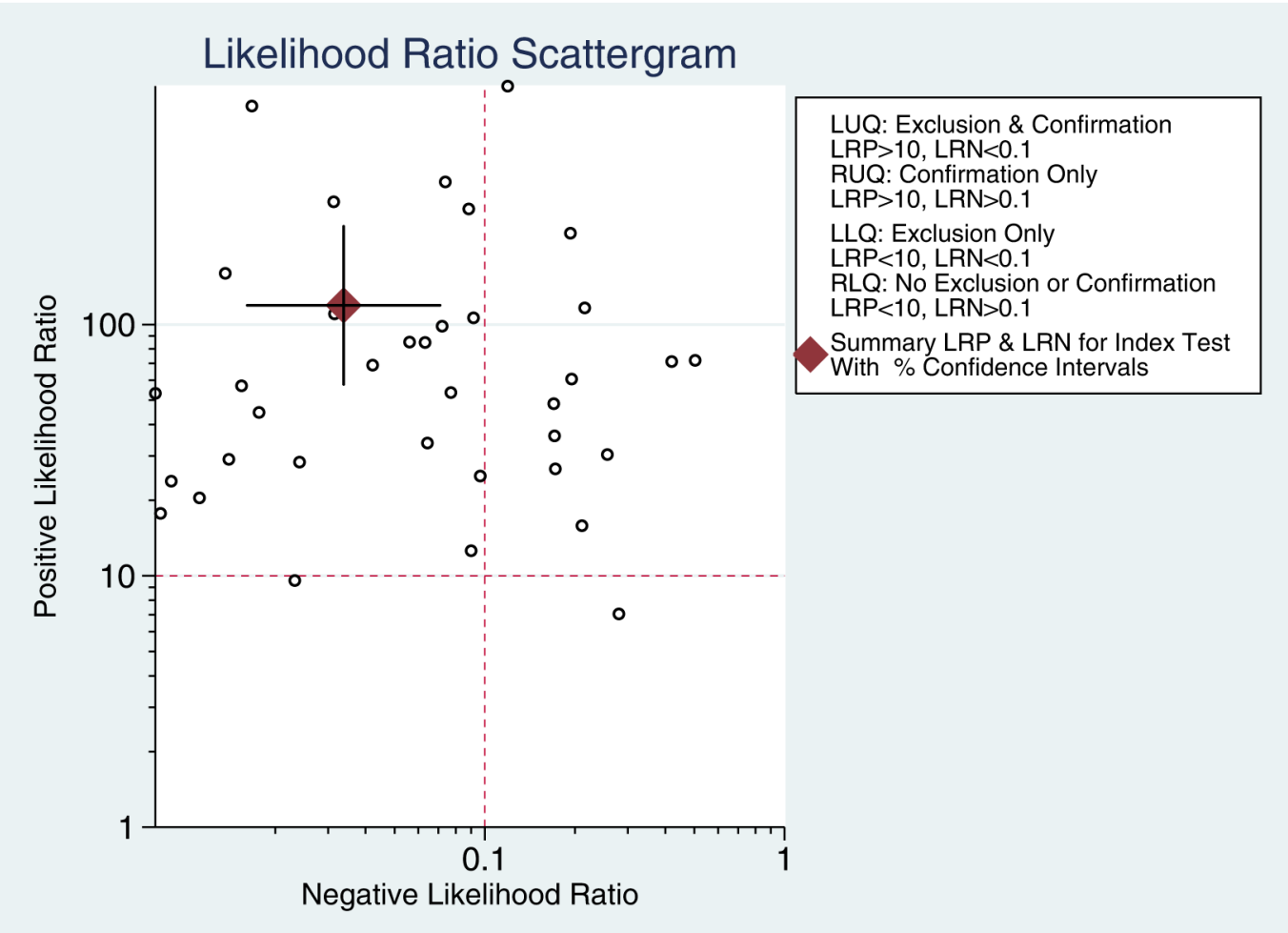

Figure 7: Likelihood ratio scattergram evaluating positive likelihood ratios ALK rearrangement detection with D5F3 IHC in NSCLC patients. Point estimates for positive likelihood ratio and 95\% CIs are shown along with pooled estimates; IHC = Immunohistochemistry; NSCLC = non-small cell lung cancer; ALK = anaplastic lymphoma kinase; $\mathrm{CI}=$ confidence interval. 
rates of nearly $14 \%$. This may be partially due to the large number of Chinese patients in our analysis; more studies are needed to examine possible differences among patient populations. Crizotinib and the newer ALK-TKIs ceritinib and alectinib are commonly used in clinical practice. While crizotinib improves progression-free survival (PFS) and response rates in NSCLC patients [52], almost all patients treated with crizotinib eventually experience progression. Ceritinib, with an overall response rate of $56 \%$ and median PFS of 7 months, is effective in ALKpositive metastatic NSCLC patients who progress during or are intolerant to crizotinib treatment [5]. Alectinib is also effective in those who progressed during crizotinib treatment, with a response rate of 50\% and an 11.2-month median duration of response; additionally, it is effective for treating CNS disease [53].

FISH, IHC, and PCR are currently used to detect ALK gene fusion in NSCLC patients. FISH, a molecular diagnostic test, has been proved by the FDA for detecting ALK rearrangements and is regarded as the gold standard by most researchers. However, FISH is expensive and relatively labor-intensive. PCR, another method for detecting ALK fusion, is associated with high false positive rates, limiting its clinical utility. Some researchers have reported that $\mathrm{IHC}$, a cost-effective and simple assay, can be used to screen for ALK rearrangements [40, 54], and three different antibodies are used for this purpose in clinical practice. D5F3, one of these antibodies, is widely used in clinics; we therefore conducted this systematic review and meta-analysis to assess the diagnostic accuracy of D5F3 IHC assays in detecting ALK rearrangement in NSCLC.

We examined 32 studies including 5805 samples among the 353 initially-identified literature citations in this study. High pooled sensitivity and specificity values indicated that D5F3 IHC had high diagnostic accuracy in detecting ALK rearrangement. Meanwhile, pooled PLR and NLR values further indicated high diagnostic accuracy for D5F3 IHC in clinical practice. Finally, pooled DOR and AUROC values indicated that D5F3 IHC had perfect discriminating ability. Although significant heterogeneity existed in our analysis, meta-regression revealed specimen type as a source of heterogeneity for specificity and specimen type and FISH signal distance as sources of heterogeneity for the joint model. Subgroup analysis revealed that sensitivity and specificity were higher when the FISH signal distance standard was $\geq 2$ compared to $\geq 1$. Finally, regarding specimen type, sensitivity was higher for tumor specimens than for cell specimens, while specificity was higher for cell specimens than for tumor specimens.

The present study expands upon the findings of Jiang et al. [17]. We searched more databases to identify studies and included more samples (5805 vs. 3754 patients),

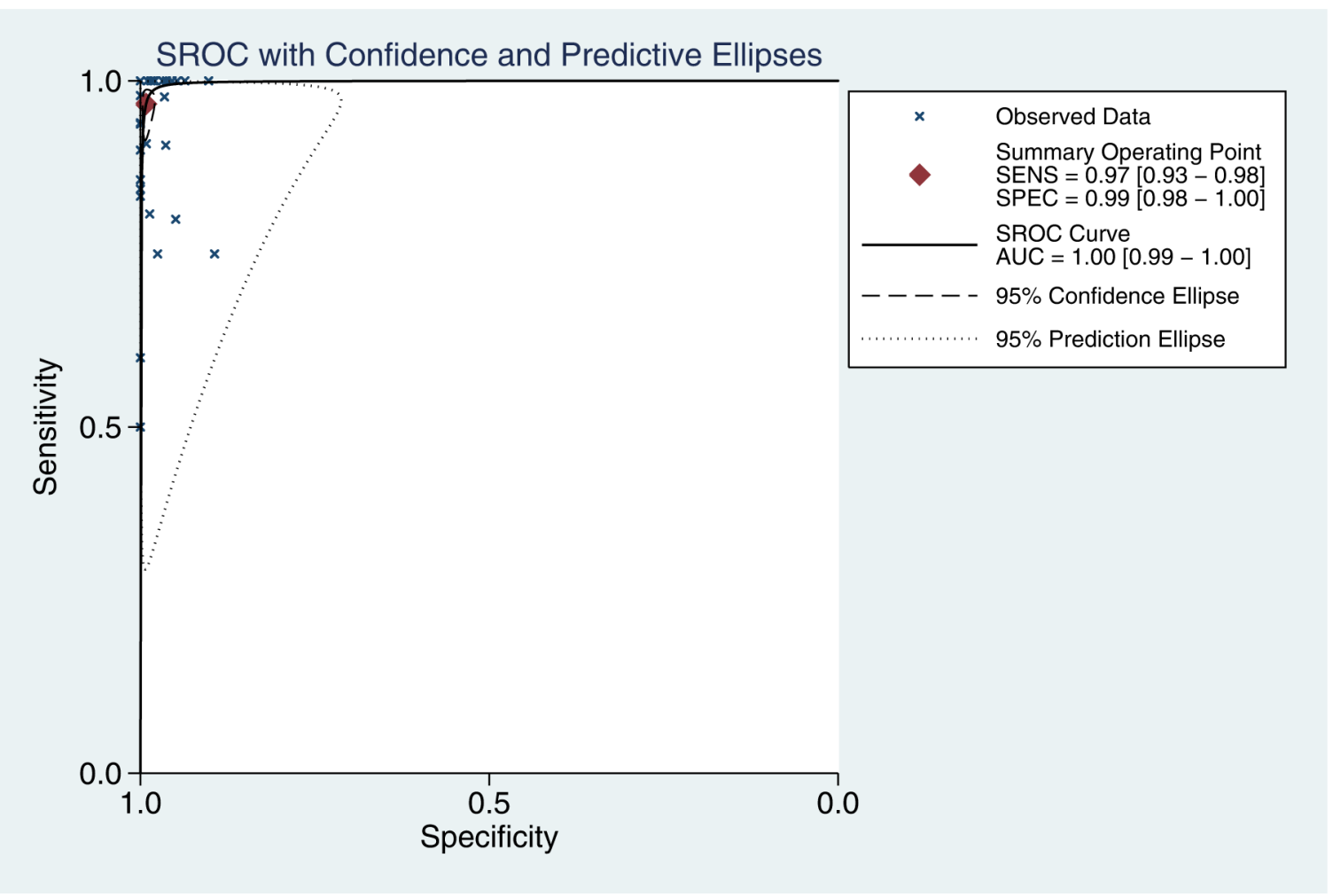

Figure 8: SROC curve for ALK rearrangement detection with the D5F3 IHC test in NSCLC patients. AUC = area under the curve; $\mathrm{IHC}=$ Immunohistochemistry; NSCLC = non-small cell lung cancer; ALK = anaplastic lymphoma kinase; SROC $=$ summary receiver-operating characteristic. 


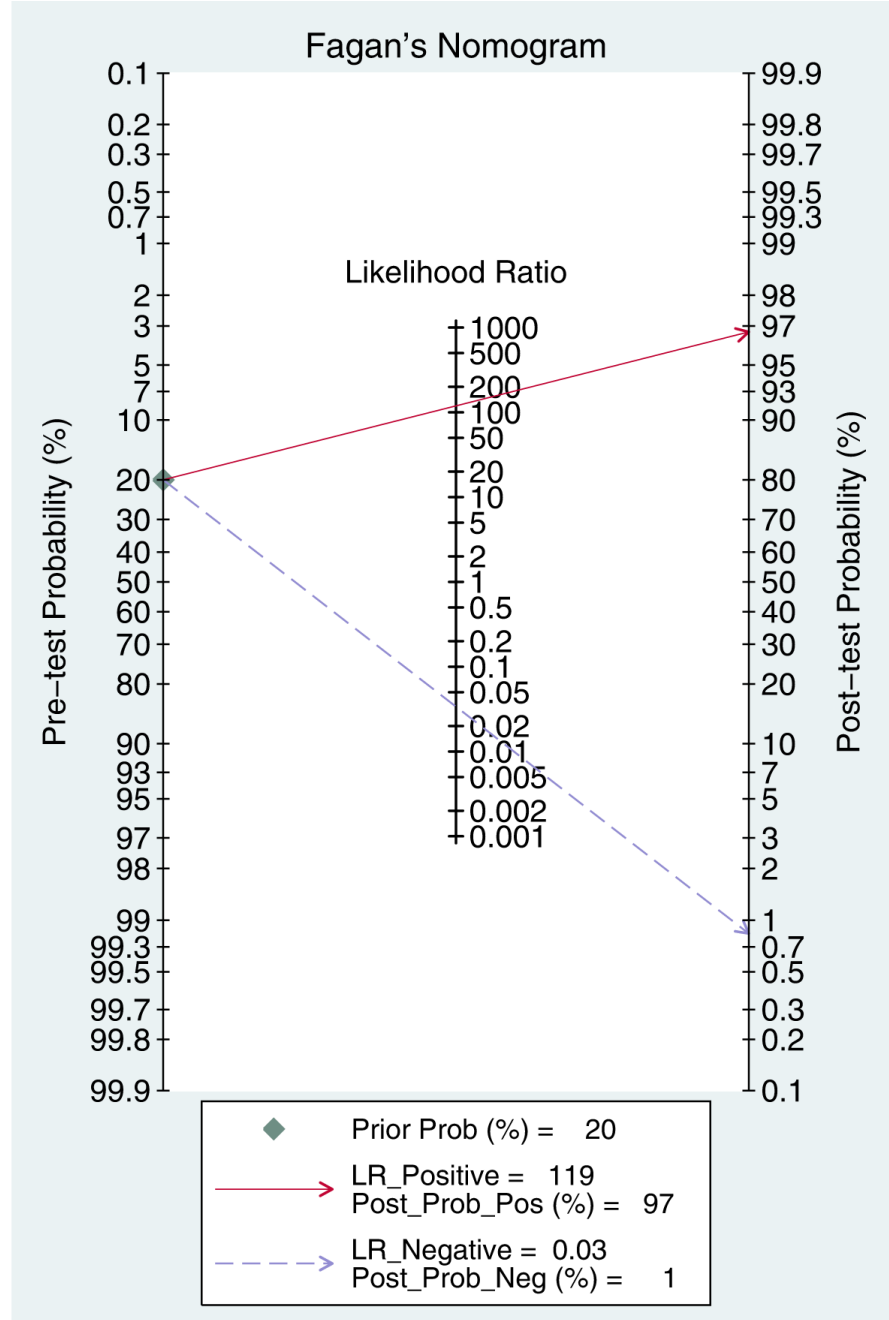

Figure 9: Fagan diagram evaluating overall diagnostic value of D5F3 IHC for ALK rearrangement detection in NSCLC patients. $\mathrm{IHC}=$ Immunohistochemistry; $\mathrm{NSCLC}=$ non-small cell lung cancer; $\mathrm{ALK}=$ anaplastic lymphoma kinase; $\mathrm{CI}=$ confidence interval.

\section{Table 1: Meta-regression results}

Table 1.1: Meta-regression of sensitivity

\begin{tabular}{lcccc}
\hline Parameter & Estimate $(\mathbf{9 5 \%} \mathbf{C I})$ & Coef & $\mathbf{Z}$ & $\boldsymbol{p}>|\mathbf{z}|$ \\
\hline Sample size & $0.97[0.93-0.98]$ & 3.34 & 0.01 & 0.99 \\
Country & $0.93[0.81-0.97]$ & 2.52 & -1.71 & 0.09 \\
Histological type & $0.96[0.89-0.99]$ & 3.17 & -0.41 & 0.68 \\
FISH cells counted & $0.95[0.88-0.98]$ & 3.04 & -0.68 & 0.49 \\
FISH signal distance & $0.97[0.93-0.98]$ & 3.36 & -0.13 & 0.90 \\
Supplier & $0.98[0.92-0.99]$ & 3.72 & 0.50 & 0.62 \\
Manual or automated & $0.96[0.88-0.99]$ & 3.20 & -0.31 & 0.76 \\
Specimen type & $0.99[0.94-1.00]$ & 4.36 & 1.55 & 0.12 \\
IHC positive standard I & $0.96[0.89-0.98]$ & 3.11 & -0.69 & 0.49 \\
IHC positive standard II & $0.94[0.86-0.98]$ & 2.84 & -1.20 & 0.23 \\
\hline
\end{tabular}


Table 1.2: Meta-regression of specificity

\begin{tabular}{|c|c|c|c|c|}
\hline Parameter & Estimate $(95 \% \mathrm{CI})$ & Coef & $\mathbf{Z}$ & $p>|z|$ \\
\hline Sample size & $0.99[0.98-1.00]$ & 4.71 & 0.00 & 1.00 \\
\hline Country & $0.99[0.98-1.00]$ & 4.90 & 0.19 & 0.85 \\
\hline Histological type & $0.99[0.97-1.00]$ & 4.61 & -0.49 & 0.62 \\
\hline FISH cells counted & $0.99[0.98-1.00]$ & 5.23 & 0.90 & 0.37 \\
\hline FISH signal distance & $0.99[0.98-1.00]$ & 4.88 & 1.75 & 0.08 \\
\hline Supplier & $1.00[0.98-1.00]$ & 5.37 & 0.79 & 0.43 \\
\hline Manual or automated & $0.99[0.97-1.00]$ & 4.58 & -0.45 & 0.66 \\
\hline Specimen type & $0.97[0.94-0.99]$ & 3.64 & -2.47 & 0.01 \\
\hline IHC positive standard I & $0.99[0.98-1.00]$ & 4.92 & 0.38 & 0.70 \\
\hline IHC positive standard II & $0.99[0.98-1.00]$ & 5.01 & 0.49 & 0.62 \\
\hline \multicolumn{5}{|c|}{ Table 1.3: Meta-regression of joint model } \\
\hline Parameter & $I^{2}(95 \% C I)$ & & LRTChi & $p$ value \\
\hline Sample size & $37.30[0.00-100.00]$ & & 3.19 & 0.20 \\
\hline Country & $41.67[0.00-100.00]$ & & 3.43 & 0.18 \\
\hline Histological type & $0.00[0.00-100.00]$ & & 0.63 & 0.73 \\
\hline FISH cells counted & $0.00[0.00-100.00]$ & & 1.59 & 0.45 \\
\hline FISH signal distance & $67.78[27.85-100.00]$ & & 6.21 & 0.04 \\
\hline Supplier & $9.21[0.00-100.00]$ & & 2.20 & 0.33 \\
\hline Manual or automated & $0.00[0.00-100.00]$ & & 0.43 & 0.81 \\
\hline Specimen type & $75.51[46.28-100.00]$ & & 8.17 & 0.02 \\
\hline IHC positive standard I & $0.00[0.00-100.00]$ & & 0.61 & 0.74 \\
\hline IHC positive standard II & $0.00[0.00-100.00]$ & & 1.70 & 0.43 \\
\hline
\end{tabular}

Sample size: $>=150$ vs. $<150$; Country: China vs. other countries; Histological type: lung adenocarcinoma vs. non-small cell lung cancer; FISH cells counted: $>=50$ vs. $>=100$; FISH signal distance: $>=1$ vs. $>=2$; Supplier: Ventana vs. other companies; Specimen type: tumor tissue vs. cell blocks; IHC Positive standard I: any percentage staining; IHC Positive standard II: any percentage staining or semi-quantitatively.

Table 2: Subgroup analysis results about specimen type and FISH signal distance

\begin{tabular}{lccc}
\hline Subgroup & & Sensitivity & Specificity \\
\hline Specimen type & Tumor & $0.984(0.960-0.996)$ & $0.965(0.951-0.976)$ \\
& Cell & $0.936(0.914-0.954)$ & $0.987(0.983-0.991)$ \\
FISH signal distance & $>=1$ & $0.952(0.881-0.987)$ & $0.963(0.933-0.982)$ \\
& $>=2$ & $0.987(0.983-0.991)$ & $0.983(0.978-0.987)$ \\
\hline
\end{tabular}

allowing our pooled analysis to more reliability evaluate the diagnostic value of IHC with the D5F3 antibody. Moreover, analysis with the QUADAS-2 tool indicated that the overall quality of the included studies was good. We also used the GRADE system to assess levels of evidence and metaregression and subgroup analysis to investigate sources of heterogeneity in our meta-analysis.
However, the limitations of this study should also be considered when interpreting these results. First, the included studies used different standards for positive IHC and FISH results, possibly reducing the diagnostic accuracy. Second, the publication bias of the studies included in this investigation was significant. Moreover, our review only included studies published in English or Chinese; potentially 


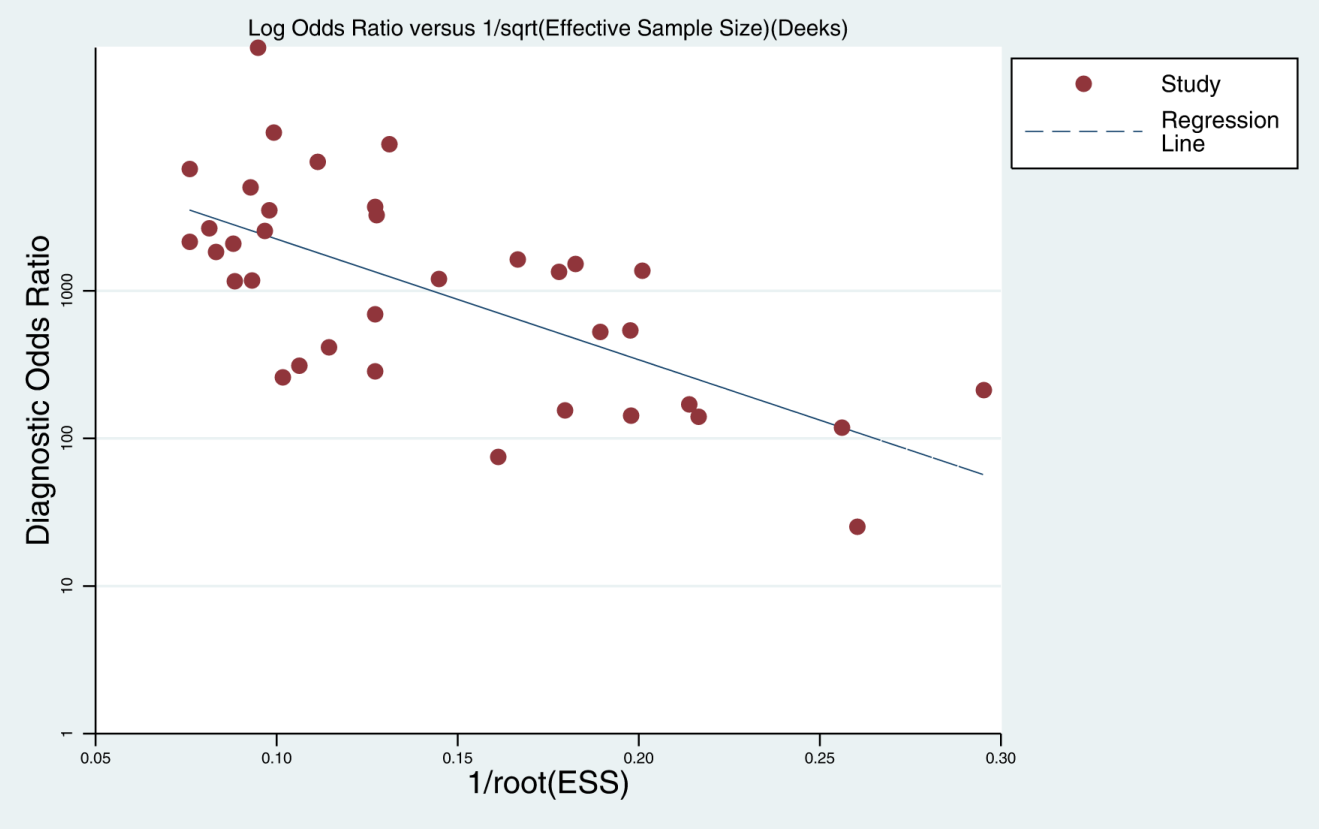

Figure 10: Deek's funnel plot evaluating publication bias

Table 3: GRADE profile of evidence for included studies

Question: Should D5F3 IHC be used to diagnose ALK gene rearrangement in NSCLC patients?

\begin{tabular}{|c|c|c|c|c|c|c|c|c|c|c|c|}
\hline Sensitivity & \multicolumn{5}{|c|}{$0.97(95 \%$ CI: 0.93 to 0.98$)$} & \multicolumn{2}{|c|}{ Prevalences $\quad 5 \% \quad 2 \%$} & $7 \%$ & & & \\
\hline Specificity & & $0.99(95$ & \% CI: 0 & 98 to 1.00$)$ & & & & & & & \\
\hline \multirow[t]{2}{*}{ Outcome } & \multirow{2}{*}{$\begin{array}{c}\text { No of } \\
\text { studies } \\
\text { (No of } \\
\text { patients) }\end{array}$} & \multirow{2}{*}{$\begin{array}{l}\text { Study } \\
\text { design }\end{array}$} & \multicolumn{5}{|c|}{ Factors that may decrease quality of evidence } & \multicolumn{3}{|c|}{ Effect per 1000 patients tested } & \multirow{2}{*}{$\begin{array}{c}\text { Test } \\
\text { accuracy } \\
\text { QoE }\end{array}$} \\
\hline & & & $\begin{array}{l}\text { Risk } \\
\text { of } \\
\text { bias }\end{array}$ & Indirectness & Inconsistency & Imprecision & $\begin{array}{l}\text { Publication } \\
\text { bias }\end{array}$ & $\begin{array}{l}\text { pre-test } \\
\text { probability } \\
\text { of } 5 \%\end{array}$ & $\begin{array}{c}\text { pre-test } \\
\text { probability } \\
\text { of } 2 \%\end{array}$ & $\begin{array}{l}\text { pre-test } \\
\text { probability } \\
\text { of } 7 \%\end{array}$ & \\
\hline $\begin{array}{l}\text { True positives } \\
\text { (patients with } \\
\text { ALK Gene } \\
\text { Rearrangement) }\end{array}$ & $\begin{array}{c}32 \\
\text { studies5805 } \\
\text { patients }\end{array}$ & $\begin{array}{c}\text { cross- } \\
\text { sectional } \\
\text { (cohort type } \\
\text { accuracy } \\
\text { study) }\end{array}$ & $\begin{array}{c}\text { not } \\
\text { serious }\end{array}$ & not serious & not serious ${ }^{1}$ & not serious & $\begin{array}{l}\text { publication } \\
\text { bias } \\
\text { strongly } \\
\text { suspected }^{2}\end{array}$ & $\begin{array}{c}49 \\
(47 \text { to } 49)\end{array}$ & $\begin{array}{c}19 \\
(19 \text { to } 20)\end{array}$ & $\begin{array}{c}68 \\
(65 \text { to } 69)\end{array}$ & $\begin{array}{c}\bigoplus \oplus \oplus \bigcirc \\
\text { MODERATE }\end{array}$ \\
\hline $\begin{array}{l}\text { False negatives } \\
\text { (patients } \\
\text { incorrectly } \\
\text { classified as not } \\
\text { having ALK gene } \\
\text { rearrangement) }\end{array}$ & & & & & & & & $\begin{array}{c}1 \\
\text { (1 to } 3)\end{array}$ & $\begin{array}{c}1 \\
(0 \text { to } 1)\end{array}$ & $\begin{array}{c}2 \\
\text { (1 to } 5)\end{array}$ & - \\
\hline $\begin{array}{l}\text { True negatives } \\
\text { (patients without } \\
\text { ALK gene } \\
\text { rearrangement) }\end{array}$ & $\begin{array}{c}32 \\
\text { studies5805 } \\
\text { patients }\end{array}$ & $\begin{array}{c}\text { cross- } \\
\text { sectional } \\
\text { (cohort type } \\
\text { accuracy } \\
\text { study) }\end{array}$ & $\begin{array}{c}\text { not } \\
\text { serious }\end{array}$ & not serious & serious $^{3}$ & not serious & $\begin{array}{l}\text { publication } \\
\text { bias } \\
\text { strongly } \\
\text { suspected }^{2}\end{array}$ & $\begin{array}{c}941 \\
\text { (931 to } 950)\end{array}$ & $\begin{array}{c}970 \\
(960 \text { to } 980)\end{array}$ & $\begin{array}{c}921 \\
\text { (911 to } 930)\end{array}$ & $\begin{array}{c}\oplus \oplus \circ \bigcirc \\
\text { LOW }\end{array}$ \\
\hline $\begin{array}{l}\text { False positives } \\
\text { (patients } \\
\text { incorrectly } \\
\text { classified as } \\
\text { having ALK gene } \\
\text { rearrangement) }\end{array}$ & & & & & & & & $\begin{array}{c}9 \\
(0 \text { to } 19)\end{array}$ & $10(0$ to 20$)$ & $\begin{array}{c}9 \\
(0 \text { to } 19)\end{array}$ & - \\
\hline
\end{tabular}

1. I square is $66 \%$

2. $\mathrm{P}=0.001$

3. I square is $88 \%$ 
relevant studies in other languages were excluded. Finally, although nonsmokers had a higher incidence of ALK gene rearrangement, we were unable to conduct subgroup analyses based on smoking status due to the limited availability of relevant information in the included studies.

In conclusion, our results indicate that IHC assays using the D5F3 antibody are nearly as effective as FISH in the detection of ALK gene rearrangement. Because IHC is more cost-effective and less labor-intensive than FISH, it might be a better method for primary ALK rearrangement screening in NSCLC patients.

\section{MATERIALS AND METHODS}

Ethical approval and informed consent were not necessary for this meta-analysis study, which was conducted according to the guidelines of the Cochrane Handbook for Diagnostic Test Accuracy Reviews, available at http://srdta.cochrane.org. The protocol is registered with the Centre for Reviews and Dissemination PROSPERO database (available at: http:/www.crd.york. ac.uk/PROSPERO/printPDF.php?RecordID=19905\&User ID=7339, Registration No. CRD42015019905).

\section{Search strategy}

A comprehensive literature search was conducted using the PubMed, EMBASE, Web of Science, Cochrane library, American Society of Clinical Oncology (ASCO), European Society for Medical Oncology (ESMO), China National Knowledge Infrastructure, China Wan Fang, and Chinese biomedical literature databases to identify studies published through March 2016. Search terms included anaplastic lymphoma kinase or ALK, immunohistochemistry or IHC, and fluorescence in situ hybridization or FISH. Only studies published in English or Chinese were examined. The reference lists of the reports selected in the original search were also examined to identify additional relevant studies. The PubMed search strategy is summarized in Supplementary Data 2.

\section{Study inclusion and exclusion criterion}

$\mathrm{Hu} \mathrm{Ma}$ and Lang Huang independently screened tiles, abstracts, and full texts, and disagreements were resolved by Jian-Guo Zhou. Eligible studies were required to meet the following criteria: (1) Patients were diagnosed with NSCLC; (2) D5F3 IHC assays were used to detect ALK fusion and compared to FISH; (3) Outcome data were presented in diagnostic $2 \times 2$ contingency tables (i.e., true positive $[\mathrm{TP}]$, false positive [FP], false negative [FN], and true negative [TN]); (4) IHC and FISH details were described; (5) Studies were designed as diagnostic tests. The exclusion criterion were as follows: (1) Reviews, meeting abstracts, or letters to the editor; (2) Insufficient data available; (3) Case reports or cohort studies.

\section{Data extraction and quality assessment}

$\mathrm{Hu} \mathrm{Ma}$ and Wen-Xiu Yao independently extracted the following information: study features (last name of the first author, year of publication, and country); number of samples; IHC and FISH details; type of specimen and outcome data (TP, FP, FN, and TN). The Quality Assessment of Diagnostic Accuracy Studies 2 (QUADAS-2) tool [18] and Review Manager 5.3 (The Nordic Cochrane Centre, The Cochrane Collaboration, 2014) were used to evaluate the methodological quality of selected studies. We assigned low, high, or unclear risk of bias values to the patient selection, index test, reference standard, and flow and timing domains; applicability concerns were also evaluated in the first three domains.

\section{Level of evidence}

Jian-Guo Zhou used GRADEpro GDT (available at http://gdt.guidelinedevelopment.org/central_prod/_ design/client/index.html), an all-in-one web solution for summarizing and presenting health care decisionmaking information, to evaluate level of evidence, and an evidence profile was generated to summarize the results. The GRADE system identified the following four rating grades of evidence quality [19]: High: further research is very unlikely to change our confidence in the effect estimate; Moderate: further research is likely to have an important impact on our confidence in the effect estimate and may change the estimate; Low: further research is very likely to have an important impact on our confidence in the effect estimate and is likely to change the estimate; and Very Low: any effect estimate is very uncertain.

\section{Statistical analysis}

A bivariate regression model [20] was used to calculate the pooled sensitivity, specificity, PLR, NLR, DOR, and AUC and associated 95\% confidence intervals (CIs). Bivariate boxplot, Chi-square, and inconsistency index $\left(I^{2}\right)$ were used to assess heterogeneity; an $I^{2}$ greater than $50 \%$ indicated significant heterogeneity [21]. Metaregression and subgroup analysis were also used to investigate potential sources of heterogeneity. In addition, a likelihood ratio scatter gram was used to evaluate the exclusion and confirmation capacities of the index test. Finally, clinical utility and publication bias were assessed by a Fagan diagram and Deek's plot. STATA version 12.0 (Stata Corp, College Station, TX) was used for statistical analyses.

\section{ACKNOWLEDGMENTS}

The authors thank the reviewers for their helpful comments on this article. 


\section{CONFLICTS OF INTEREST}

There is no conflict of interest for any author regarding the publication of this manuscript.

\section{GRANT SUPPORT}

This research was supported by the NSFC (Natural Science Foundation of China) (81360351, 81660512), the Department of Science and Technology of Guizhou Province (Grant No. Qian Ke He SY [2013] 3003), the High-level Innovative Talents Cultivation Program of Guizhou Province, the Start-Up Fund for Doctors of Zunyi Medical University, and the Social Practice Program for Postgraduates of Zunyi Medical University (Grant No. zy-yjs2015004), Applied Basic Research Programs of Science and Technology Commission Foundation of Sichuan Province (Grant No. 2012JY0058). The funders had no role in study design, data collection and analysis, decision to publish, or preparation of the manuscript. The authors thank the reviewers for their helpful comments on this article.

\section{REFERENCES}

1. Siegel RL, Miller KD, Jemal A. Cancer statistics, 2016. CA Cancer J Clin. 2016; 66: 7-30. doi: 10.3322/caac.21332.

2. Torre LA, Bray F, Siegel RL, Ferlay J, Lortet - Tieulent J, Jemal A. Global cancer statistics, 2012. CA Cancer J Clin. 2015; 65: 87-108. doi: 10.3322/caac.20107.

3. Soda M, Choi YL, Enomoto M, Takada S, Yamashita Y, Ishikawa S, Fujiwara S, Watanabe H, Kurashina K, Hatanaka H, Bando M, Ohno S, Ishikawa Y, et al. Identification of the transforming EML4-ALK fusion gene in non-small-cell lung cancer. Nature. 2007; 448: 561-6. doi: 10.1038/nature05945.

4. Rikova K, Guo A, Zeng Q, Possemato A, Yu J, Haack H, Nardone J, Lee K, Reeves C, Li Y, Hu Y, Tan Z, Stokes M, et al. Global survey of phosphotyrosine signaling identifies oncogenic kinases in lung cancer. Cell. 2007; 131: 1190203. doi: 10.1016/j.cell.2007.11.025.

5. Shaw AT, Kim DW, Mehra R, Tan DS, Felip E, Chow LQ, Camidge DR, Vansteenkiste J, Sharma S, De Pas T, Riely GJ, Solomon BJ, Wolf J, et al. Ceritinib in ALK-rearranged non-small-cell lung cancer. N Engl J Med. 2014; 370: 118997. doi: 10.1056/NEJMoa1311107.

6. Solomon BJ, Mok T, Kim DW, Wu YL, Nakagawa K, Mekhail T, Felip E, Cappuzzo F, Paolini J, Usari T, Iyer S, Reisman A, Wilner KD, et al. First-line crizotinib versus chemotherapy in ALK-positive lung cancer. N Engl J Med. 2014; 371: 2167-77. doi: 10.1056/NEJMoa1408440.

7. Crino L, Kim D, Riely G, Janne P, Blackhall F, Camidge D, Hirsh V, Mok T, Solomon B, Park K. (2011). Initial phase II results with crizotinib in advanced ALK-positive non-small cell lung cancer (NSCLC): PROFILE 1005. ASCO Annual Meeting Proceedings, pp. 7514.

8. Shaw AT, Kim DW, Nakagawa K, Seto T, Crino L, Ahn MJ. Crizotinib versus Chemotherapy in Advanced ALKPositive Lung Cancer. New England Journal of Medicine. 2013; 368: 2385-94. doi: 10.1056/NEJMoa1214886.

9. Ettinger DS, Wood DE, Akerley W, Bazhenova LA, Borghaei H, Camidge DR, Cheney RT, Chirieac LR, D’Amico TA, Dilling TJ, Dobelbower MC, Govindan R, Hennon M, et al. NCCN Guidelines Insights: Non-Small Cell Lung Cancer, Version 4.2016. J Natl Compr Canc Netw. 2016; 14: 255-64.

10. Yi ES, Boland JM, Maleszewski JJ, Roden AC, Oliveira AM, Aubry MC, Erickson-Johnson MR, Caron BL, Li Y, Tang H, Stoddard S, Wampfler J, Kulig K, et al. Correlation of IHC and FISH for ALK Gene Rearrangement in Nonsmall Cell Lung Carcinoma IHC Score Algorithm for FISH. Journal of Thoracic Oncology. 2011; 6: 459-65. doi: 10.1097/JTO.0b013e318209edb9.

11. Robesova B, Bajerova M, Liskova K, Skrickova J, Tomiskova M, Pospisilova S, Mayer J, Dvorakova D. TaqMan based real time PCR assay targeting EML4-ALK fusion transcripts in NSCLC. Lung Cancer. 2014; 85: 25-30. doi: 10.1016/j.lungcan.2014.04.002.

12. Zhou J, Yao H, Zhao J, Zhang S, You Q, Sun K, Zou Y, Zhou C, Zhou J. Cell block samples from malignant pleural effusion might be valid alternative samples for anaplastic lymphoma kinase detection in patients with advanced nonsmall-cell lung cancer. Histopathology. 2015; 66: 949-54. doi: $10.1111 /$ his. 12560 .

13. Sasaki T, Rodig SJ, Chirieac LR, Jänne PA. The biology and treatment of EML4-ALK non-small cell lung cancer. European journal of cancer. 2010; 46: 1773-80. doi: 10.1016/j.ejca.2010.04.002.

14. Ilie MI, Bence C, Hofman V, Long-Mira E, Butori C, Bouhlel L, Lalvee S, Mouroux J, Poudenx M, Otto J, Marquette CH, Hofman P. Discrepancies between FISH and immunohistochemistry for assessment of the ALK status are associated with ALK 'borderline'-positive rearrangements or a high copy number: A potential major issue for antiALK therapeutic strategies. Annals of Oncology. 2015; 26: 238-44. doi: 10.1093/annonc/mdu484.

15. Shan L, Lian F, Guo L, Yang X, Ying J, Lin D. Combination of conventional immunohistochemistry and qRT-PCR to detect ALK rearrangement. Diagnostic pathology. 2014; 9: 3. doi: 10.1186/1746-1596-9-3.

16. Hofman $\mathrm{P}$, Ilie $\mathrm{M}$, Hofman $\mathrm{V}$, Roux $\mathrm{S}$, Valent $\mathrm{A}$, Bernheim A, Alifano M, Leroy-Ladurie F, Vaylet F, Rouquette I, Validire P, Beau-Faller M, Lacroix L, et al. Immunohistochemistry to identify EGFR mutations or ALK rearrangements in patients with lung adenocarcinoma. Ann Oncol. 2012; 23: 1738-43. doi: 10.1093/annonc/mdr535.

17. Jiang L, Yang H, He P, Liang W, Zhang J, Li J, Liu Y, He J. Improving Selection Criteria for ALK Inhibitor Therapy in Non-Small Cell Lung Cancer: A Pooled-Data Analysis on Diagnostic Operating Characteristics of 
Immunohistochemistry. Am J Surg Pathol. 2016; 40: $697-$ 703. doi: 10.1097/pas.0000000000000604.

18. Whiting PF, Rutjes AW, Westwood ME, Mallett S, Deeks JJ, Reitsma JB, Leeflang MM, Sterne JA, Bossuyt PM. QUADAS-2: a revised tool for the quality assessment of diagnostic accuracy studies. Annals of internal medicine. 2011; 155: 529-36. doi: 10.7326/0003-4819-155-8-201110180-00009.

19. Ma H, Tian X, Zeng X-T, Zhang Y, Wang Y, Wang F, Zhou J-G. The Efficacy of Erlotinib Versus Conventional Chemotherapy for Advanced Nonsmall-Cell Lung Cancer: A PRISMA-Compliant Systematic Review With MetaRegression and Meta-Analysis. Medicine. 2016; 95: e2495. doi: 10.1097/MD.0000000000002495.

20. Reitsma JB, Glas AS, Rutjes AW, Scholten RJ, Bossuyt $\mathrm{PM}$, Zwinderman AH. Bivariate analysis of sensitivity and specificity produces informative summary measures in diagnostic reviews. Journal of clinical epidemiology. 2005; 58: 982-90. doi: 10.1016/j.jclinepi.2005.02.022.

21. Ma H, Liu Y, Huang L, Zeng X-T, Jin S-H, Yue G-J, Tian $\mathrm{X}$, Zhou J-G. The Adverse Events of Oxycodone in CancerRelated Pain: A Systematic Review and Meta-Analysis of Randomized Controlled Trials. Medicine. 2016; 95: e3341. doi: 10.1097/MD.0000000000003341.

22. Wen YQ, Liang YQ, Liao YQ. Relationship between the clinical pathological features and ALK rearrangements in patients with primary lung adenocarcinoma. China Tropical Medicine. 2015; 15: 200-3.

23. Wang X, Chen W, Yu Y. [Analysis of EML4-ALK gene fusion mutation in patients with non-small cell lung cancer]. [Article in Chinese]. Zhongguo Fei Ai Za Zhi. 2015; 18:80-4.

24. Shen Q, Wang X, Yu B, Shi S, Liu B, Wang Y, Xia Q, Rao Q, Zhou X. Comparing four different ALK antibodies with manual immunohistochemistry (IHC) to screen for ALK-rearranged non-small cell lung cancer (NSCLC). Lung Cancer. 2015; 90: 492-8. doi: 10.1016/j. lungcan.2015.10.002.

25. Zhu P, Pan Q, Wang M, Zhong W, Zhao J. Efficacy of bronchoscopic biopsy for the detection of epidermal growth factor receptor mutations and anaplastic lymphoma kinase gene rearrangement in lung adenocarcinoma. Thoracic Cancer. 2015; 6: 709-14. doi: 10.1111/1759-7714.12245.

26. Wang W, Tang Y, Li J, Jiang L, Jiang Y, Su X. Detection of ALK Rearrangements in Malignant Pleural Effusion Cell Blocks From Patients With Advanced Non-Small Cell Lung Cancer: A Comparison of Ventana Immunohistochemistry and Fluorescence In Situ Hybridization. Cancer Cytopathology. 2015; 123: 117-22. doi: 10.1002/ cncy.21510.

27. Liu L, Zhan P, Zhou X, Song Y, Zhou X, Yu L, Wang J. Detection of EML4-ALK in Lung Adenocarcinoma Using Pleural Effusion with FISH, IHC, and RT-PCR Methods.
PLoS One. 2015; 10: e0117032. doi: 10.1371/journal. pone.0117032.

28. Fu S, Wang F, Shao Q, Zhang X, Duan LP, Zhang X, Zhang L, Shao JY. Detection of EML4-ALK Fusion Gene in Chinese Non-Small Cell Lung Cancer by Using a Sensitive Quantitative Real-Time Reverse Transcriptase PCR Technique. Appl Immunohistochem Mol Morphol. 2015; 23: 245-54. doi: 10.1097/pdm.0000000000000038.

29. Wang J, Cai Y, Dong Y, Nong J, Zhou L, Liu G, Su D, Li X, Wu S, Chen X, Qin N, Zeng X, Zhang H, et al. Clinical characteristics and outcomes of patients with primary lung adenocarcinoma harboring ALK rearrangements detected by FISH, IHC, and RT-PCR. PLoS ONE. 2014; 9: e101551. doi: 10.1371/journal.pone.0101551.

30. Liang X, Wang M, Zhang J. [ALK protein expression and gene fusion in bronchoscopic specimens of lung adenocarcinoma]. [Article in Chinese]. Zhonghua Zhong Liu Za Zhi. 2014; 36:501-4. doi: 10.3760/cma.j.issn.0253-3766.2014.07.005.

31. Zhou J, Zhao J, Sun K, Wang B, Wang L, Chen X, Zheng J, You Q, Wang X, Ding W, Zhou J. Accurate and economical detection of ALK positive lung adenocarcinoma with semiquantitative immunohistochemical screening. PLoS ONE. 2014; 9: e92828. doi: 10.1371/journal.pone.0092828.

32. Zhang NN, Liu YT, Ma L, Wang L, Hao XZ, Yuan Z, Lin DM, Li D, Zhou YJ, Lin H, Han XH, Sun Y, Shi Y. The molecular detection and clinical significance of ALK rearrangement in selected advanced non-small cell lung cancer: ALK expression provides insights into ALK targeted therapy. PLoS One. 2014; 9: e84501. doi: 10.1371/ journal.pone.0084501.

33. Wynes MW, Sholl LM, Dietel M, Schuuring E, Tsao MS, Yatabe Y, Tubbs RR, Hirsch FR. An international interpretation study using the ALK IHC antibody D5F3 and a sensitive detection kit demonstrates high concordance between ALK IHC and ALK FISH and between evaluators. Journal of thoracic oncology. 2014; 9: 631-8. doi: 10.1097/ JTO.0000000000000115.

34. Tantraworasin A, Lertprasertsuke N, Kongkarnka S, Euathrongchit J, Wannasopha Y, Saeteng S. Retrospective Study of ALK Rearrangement and Clinicopathological Implications in Completely Resected Non-small Cell Lung Cancer Patients in Northern Thailand: Role of Screening with D5F3 Antibodies. Asian Pacific Journal of Cancer Prevention. 2014; 15: 3057-63. doi: 10.7314/ apjcp.2014.15.7.3057.

35. LeQuesne J, Maurya M, Yancheva SG, O’Brien M, Popat S, Wotherspoon AC, DeCastro DG, Nicholson AG. A comparison of immunohistochemical assays and FISH in detecting the ALK translocation in diagnostic histological and cytological lung tumor material. Journal of thoracic oncology. 2014; 9: 769-74. doi: 10.1097/ JTO.0000000000000157.

36. Kotoula V, Bobos M, Vassilakopoulou M, Tsolaki E, Chrisafi S, Psyrri A, Lazaridis G, Papadopoulou K, Efstratiou I, Michail-Strantzia C, Debelenko LV, Kosmidis 
P, Fountzilas G. Intact or broken-apart RNA: An alternative concept for alk fusion screening in non-small cell lung cancer (NSCLC). Applied Immunohistochemistry and Molecular Morphology. 2014; 23: 60-70. doi: 10.1097/ PAI.0000000000000028.

37. Guo L, Liu X, Qiu T, Ling Y, Shan L, Xie Y. [ALK fusion gene assessment by fully automatic immunohistochemistry in non-small cell lung cancer]. [Article in Chinese]. Zhonghua Bing Li Xue Za Zhi. 2014; 43:95-8. doi: 10.3760/ cma.j.issn.0529-5807.2014.02.005.

38. Demidova I, Barinov A, Savelov N, Gagarin I, Grinevitch V, Stroiakovaski D, Popov M, Laktionov K, Gutorov S, Smolin A, Olshanskaya Y, Obukhova T. Immunohistochemistry, Fluorescence in Situ Hybridization, and Reverse Transcription-Polymerase Chain Reaction for the Detection of Anaplastic Lymphoma Kinase Gene Rearrangements in Patients With Non-Small Cell Lung Cancer Potential Advantages and Methodologic Pitfalls. Archives of Pathology \& Laboratory Medicine. 2014; 138: 794-802. doi: 10.5858/arpa.2012-0762-OA.

39. Conde E, Suarez-Gauthier A, Benito A, Garrido P, Garcia-Campelo R, Biscuola M, Paz-Ares L, Hardisson D, De Castro J, Camacho MC, RodriguezAbreu D, Abdulkader I, Ramirez J, et al. Accurate identification of ALK positive lung carcinoma patients: Novel FDA-cleared automated fluorescence in situ hybridization scanning system and ultrasensitive immunohistochemistry. PLoS ONE. 2014; 9: e107200. doi: 10.1371/journal.pone.0107200.

40. Ali G, Proietti A, Pelliccioni S, Niccoli C, Lupi C, Sensi E, Giannini R, Borrelli N, Menghi M, Chella A, Ribechini A, Cappuzzo F, Melfi F, et al. ALK rearrangement in a large series of consecutive non-small cell lung cancers: comparison between a new immunohistochemical approach and fluorescence in situ hybridization for the screening of patients eligible for crizotinib treatment. Arch Pathol Lab Med. 2014; 138: 1449-58. doi: 10.5858/ arpa.2013-0388-OA.

41. Ying J, Guo L, Qiu T, Shan L, Ling Y, Liu X, Lu N. Diagnostic value of a novel fully automated immunochemistry assay for detection of ALK rearrangement in primary lung adenocarcinoma. Annals of oncology. 2013; 24: 2589-93. doi: 10.1093/annonc/mdt295.

42. Selinger CI, Rogers TM, Russell PA, O'Toole S, Yip P, Wright GM, Wainer Z, Horvath LG, Boyer M, McCaughan B, Kohonen-Corish MR, Fox S, Cooper WA, et al. Testing for ALK rearrangement in lung adenocarcinoma: a multicenter comparison of immunohistochemistry and fluorescent in situ hybridization. Mod Pathol. 2013; 26: 1545-53. doi: 10.1038/modpathol.2013.87.

43. Minca EC, Portier BP, Wang Z, Lanigan C, Farver CF, Feng Y, Ma PC, Arrossi VA, Pennell NA, Tubbs RR. ALK status testing in non-small cell lung carcinoma: Correlation between ultrasensitive IHC and FISH. The Journal of molecular diagnostics. 2013; 15: 341-6. doi: 10.1016/j. jmoldx.2013.01.004.

44. Martinez P, Hernandez-Losa J, Montero MA, Cedres S, Castellvi J, Martinez-Marti A, Tallada N, Murtra-Garrell N, Navarro-Mendivill A, Rodriguez-Freixinos V, Canela M, Ramon y Cajal S, Felip E. Fluorescence in situ hybridization and immunohistochemistry as diagnostic methods for ALK positive non-small cell lung cancer patients. PLoS One. 2013; 8: e52261. doi: 10.1371/ journal.pone.0052261.

45. Li Y, Pan Y, Wang R, Sun Y, Hu H, Shen X, Lu Y, Shen L, Zhu X, Chen H. ALK-Rearranged Lung Cancer in Chinese: A Comprehensive Assessment of Clinicopathology, IHC, FISH and RT-PCR. Plos One. 2013; 8: e69016. doi: 10.1371/journal.pone.0069016.

46. Han XH, Zhang NN, Ma L, Lin DM, Hao XZ, Liu YT, Wang L, Liu P, Yuan Z, Li D, Lin H, Sun Y, Shi YK. Immunohistochemistry reliably detects ALK rearrangements in patients with advanced non-smallcell lung cancer. Virchows Arch. 2013; 463: 583-91. doi: 10.1007/s00428-013-1472-7.

47. Pang Q. (2012). Evaluate the Status of ALK Gene in Bronchoscopic Samples of Lung Adenocarcinoma Patients. [D]. Beijing: Peking Union Medical College).

48. Chen Y, Gao L, Wang Y. [Anaplastic lymphoma kinasepositive adenocarcinoma of lung: a cytopathologic analysis]. [Article in Chinese]. Zhonghua Bing Li Xue Za Zhi. 2015; 44:628-32. doi: 10.3760/cma.j.issn.0529-5807.2015.09.004.

49. Pekar-Zlotin M, Hirsch FR, Soussan-Gutman L, Ilouze M, Dvir A, Boyle T, Wynes M, Miller VA, Lipson D, Palmer GA, Ali SM, Dekel S, Brenner R, et al. Fluorescence In Situ Hybridization, Immunohistochemistry, and NextGeneration Sequencing for Detection of EML4-ALK Rearrangement in Lung Cancer. Oncologist. 2015; 20: 31622. doi: 10.1634/theoncologist.2014-0389.

50. Minca EC, Lanigan CP, Reynolds JP, Wang Z, Ma PC, Cicenia J, Almeida FA, Pennell NA, Tubbs RR. ALK status testing in non-small-cell lung carcinoma by FISH on ThinPrep slides with cytology material. Journal of thoracic oncology. 2014; 9: 464-8. doi: 10.1097/ JTO.0000000000000104.

51. Soda M, Choi YL, Enomoto M, Takada S, Yamashita Y, Ishikawa S, Fujiwara S-i, Watanabe H, Kurashina K, Hatanaka H, Bando M, Ohno S, Ishikawa Y, et al. Identification of the transforming EML4-ALK fusion gene in non-small-cell lung cancer. Nature. 2007; 448: 561-U3. doi: 10.1038/nature05945.

52. Shaw AT, Kim DW, Nakagawa K, Seto T, Crino L, Ahn MJ, De Pas T, Besse B, Solomon BJ, Blackhall F, Wu YL, Thomas M, O'Byrne KJ, et al. Crizotinib versus chemotherapy in advanced ALK-positive lung cancer. N Engl J Med. 2013; 368: 2385-94. doi: 10.1056/ NEJMoa1214886. 
53. Ou SH, Ahn JS, De Petris L, Govindan R, Yang JC, Hughes B, Lena H, Moro-Sibilot D, Bearz A, Ramirez SV, Mekhail T, Spira A, Bordogna W, et al. Alectinib in CrizotinibRefractory ALK-Rearranged Non-Small-Cell Lung Cancer: A Phase II Global Study. J Clin Oncol. 2016; 34: 661-8. doi: 10.1200/jco.2015.63.9443.

54. Lindeman NI, Cagle PT, Beasley MB, Chitale DA, Dacic S, Giaccone G, Jenkins RB, Kwiatkowski DJ, Saldivar
JS, Squire J, Thunnissen E, Ladanyi M. Molecular testing guideline for selection of lung cancer patients for EGFR and ALK tyrosine kinase inhibitors: guideline from the College of American Pathologists, International Association for the Study of Lung Cancer, and Association for Molecular Pathology. J Thorac Oncol. 2013; 8: 823-59. doi: 10.1097/ JTO.0b013e318290868f. 